\title{
Ethanol Production from Oil Palm Trunk: A Combined Strategy Using an Effective Pretreatment and Simultaneous Saccharification and Cofermentation
}

\author{
Agustin Krisna Wardani ${ }^{1 D},{ }^{1}$ Aji Sutrisno ${ }^{D},{ }^{1}$ Titik Nur Faida ${ }^{(D},{ }^{1}$ Retno Dwi Yustina ${ }^{1 D},{ }^{2}$ \\ and Untung Murdiyatmo $\mathbb{D}^{3}$ \\ ${ }^{1}$ Department of Agricultural Product Technology, Universitas Brawijaya, Malang 65314, East Java, Indonesia \\ ${ }^{2}$ Department of Research and Development, PT Sampoerna Agro Tbk, Palembang 30128, South Sumatera, Indonesia \\ ${ }^{3}$ Indonesian Ethanol Association, Malang, Indonesia
}

Correspondence should be addressed to Agustin Krisna Wardani; agustinwardani@ub.ac.id

Received 2 June 2021; Revised 29 October 2021; Accepted 12 November 2021; Published 23 December 2021

Academic Editor: Giuseppe Comi

Copyright (c) 2021 Agustin Krisna Wardani et al. This is an open access article distributed under the Creative Commons Attribution License, which permits unrestricted use, distribution, and reproduction in any medium, provided the original work is properly cited.

Background. Oil palm trunk (OPT) with highly cellulose content is a valuable bioresource for bioethanol production. To produce ethanol from biomass, pretreatment is an essential step in the conversion of lignocellulosic biomass to fermentable sugars such as glucose and xylose. Several pretreatment methods have been developed to overcome biomass recalcitrance. In this study, the effects of different pretreatment methods such as alkali pretreatment, microwave-alkali, and alkaline peroxide combined with autoclave on the lignocellulosic biomass structure were investigated. Moreover, ethanol production from the treated biomass was performed by simultaneous saccharification and cofermentation (SSCF) under different temperatures, fermentation times, and cell ratios of Saccharomyces cerevisiae NCYC 479 and pentose-utilizing yeast, Pichia stipitis NCYC 1541. Results. Pretreatment resulted in a significant lignin removal up to $83.26 \%$ and cellulose released up to $80.74 \%$ in treated OPT by alkaline peroxide combined with autoclave method. Enzymatic hydrolysis of treated OPT resulted in an increase in fermentable sugar up to $93.22 \%$. Optimization of SSCF by response surface method showed that the coculture could work together to produce maximum ethanol $(1.89 \%)$ and fermentation efficiency $(66.14 \%)$ under the optimized condition. Conclusion. Pretreatment by alkaline peroxide combined with autoclave method and SSCF process could be expected as a promising system for ethanol production from oil palm trunk and various lignocellulosic biomass.

\section{Introduction}

The development of biorefining process technologies to produce biofuels from renewable biomass sources represent a key tool to perform the transition from a fossil fuel-based economy to a novel bioeconomy that looks for a more efficient and sustainable global development $[1,2]$. According to the biorefinery concepts, there are many kinds of biomass feedstocks used, such as sugar, starch, aquatic biomass, organic residues, and lignocellulose, or oil-containing crops, can be converted into bioenergy products. Bioethanol is one of renewable biomass energy produced via sugar fermentation and can be a potential source of sustainable fuel. It has been proposed that an alternative feedstock for biofuel is wasted crops, replacing the traditional starch crop and can avoid conflicts with human food uses.

Indonesia is one of the largest producers of palm oil in the world. In 2010, oil palm plantations produced 22 million tonnes of Crude Palm Oil (CPO), while in 2011, it was 23.5 million tonnes [3]. By 2020, Indonesia plans to double the current production of $\mathrm{CPO}$ to 40 million tonnes annually and expand its oil palm plantation portfolio by additional 4 million hectares. Along with the growing palm oil industry, it creates the availability of palm oil residue, including oil palm trunk (OPT) waste, which is considered a great potential source of renewable energy. Oil palm trunk contains 
approximately $70 \%$ sugar and 30\% (w/w) cellulosic residue. This indicates that OPT is a very promising material to be used as feedstock for second-generation ethanol production.

In general, the production of ethanol from lignocellulose requires several stages, including delignification, saccharification to liberate fermentable hexoses and pentoses of polysaccharides, released sugar fermentation, and distillation stage to separate the ethanol $[4,5]$. Delignification is the essential step to effectively prepare cellulose to be used by fermenting microorganism for ethanol production $[6,7]$. Some strategies for pretreatment such as microwave, ultrasound, deep eutectic solvent, irradiation, and ionic liquids methods have been applied to decrease the recalcitrance of biomass [8-10]. However, the major problem is the involvement of high capital cost and the low effectiveness for lignin removal. In this study, some pretreatment methods, such as alkali, alkali-microwave, and alkaline peroxide combined with autoclaves, were used to remove the lignin content of the oil palm trunk. In addition, the simultaneous saccharification and cofermentation (SSCF) system was chosen to maximize the utilization of hexose and pentose sugars by Saccharomyces cerevisiae NCYC 479 and Pichia stipitis NCYC 1541. The SSCF system has some additional advantages as follows: (1) the existence of yeast and enzyme complexes together reduce the accumulation of glucose and short cellulose oligomers which can inhibit the enzyme and thus be able to increase the yield of ethanol and saccharification rate; (2) the use of one bioreactor can reduce investment costs; (3) the presence of ethanol in the bioreactor and the rapid consumption of sugar by yeast reduce the risk of contamination [11-13]. Simultaneous saccharification and cofermentation (SSCF) system is influenced by many factors, such as cell ratio, temperature, and fermentation time [14]. In the current study, optimization of fermentation process parameters for $S$. cerevisiae and $P$. stipitis coculture was performed using RSM. Parameters examined in this study were cell ratio between $S$. cerevisiae and $P$. stipitis, culture temperature, and fermentation time. Cell ratio between $S$. cerevisiae and $P$. stipitis related to assimilation rate of glucose and xylose by the yeasts. Thus, this parameter is considered a major factor in ethanol production efficiency. Temperature and fermentation time is also a key factor in yeast growth. Therefore, these parameters were also optimized for ethanol fermentation [15, 16]. Response Surface Methodology (RSM) with a full factorial central composite design (CCD) was applied to optimize fermentation to maximize ethanol production and fermentation efficiency. This method intends to find an appropriate function to predict the response (ethanol content and fermentation efficiency) and determine the value of the independent variables (cell ratio, temperature, and fermentation time) that provide an optimal response.

\section{Materials and Methods}

2.1. Materials. The oil palm trunk (OPT), estimated to be 25 years old, was collected from the plantation of PT Sampoerna Agro Tbk., Indonesia. Ten $\mathrm{cm}$ in thickness of disks trunk was taken from the middle part of each trunk, which ranged from 10 to $12 \mathrm{~m}$ in length. A laboratory-scale crusher was used to make disks trunk into small particles. The sap was squeezed from the disks using a laboratory-scale press at 250 Bar. The free sugars remaining in the disks were removed by twice washing with distilled water. The moisture content of crushed disks was reduced to $<5 \%$ using an oven $\left(60^{\circ} \mathrm{C}\right.$ for $\left.48 \mathrm{~h}\right)$. The dried disks were pounded manually into small pieces until the mixed fiber was ready to separate into parenchyma (PA) and vascular bundle (VB) by using 30 mesh $(0.6 \mathrm{~mm})$ and 80 mesh screen $(0.2 \mathrm{~mm})$. The retained particles on the 80 mesh screen (VB) were used as the raw material for ethanol production.

2.2. Alkali Pretreatment. Ten percent of raw materials (dried $\mathrm{VB})$ were pretreated with dilute sodium hydroxide $(\mathrm{NaOH})$ at a concentration of $5 \%(\mathrm{w} / \mathrm{v}) \mathrm{NaOH}$. Then, the mixtures were heated at $150^{\circ} \mathrm{C}$ for $3 \mathrm{~h}$. The mixture was filtered to separate solid residues and thoroughly washed with distilled water to neutral $\mathrm{pH}$. Finally, it was dried in the oven at $105^{\circ} \mathrm{C}$ for $48 \mathrm{~h}$.

2.3. Alkali-Peroxide Pretreatment. Raw materials were pretreated with $250 \mathrm{ml}$ of $\mathrm{H}_{2} \mathrm{O}_{2} 5 \%(\mathrm{v} / \mathrm{v})$ solution in an autoclavable bottle. The mixture was adjusted to $\mathrm{pH} 11.5$ using sodium hydroxide $(\mathrm{NaOH})$ and incubated at room temperature for 3 days. To remove the moisture, it was heated at $121^{\circ} \mathrm{C}$ for 15 minutes, 1 atm, using autoclave. After heating, the raw material slurry was filtered to recover the insoluble solids. The solids were washed with distilled water until the $\mathrm{pH}$ of the solid became neutral. The washed treated raw materials were dried in a drying oven at $105^{\circ} \mathrm{C}$ for $48 \mathrm{~h}$. After drying, the moisture content of treated raw materials was measured.

2.4. Alkali-Microwave Pretreatment. Raw materials (dried VB) were pretreated with dilute sodium hydroxide $(\mathrm{NaOH})$ at a concentration of $5 \%(\mathrm{w} / \mathrm{v}) \mathrm{NaOH}$ and at solid loading of $10 \%$. Then, the mixtures were placed in an open $250 \mathrm{ml}$ glass beaker and exposed to microwave radiation at 400 watts for 30 minutes and 800 watts for 80 minutes. The mixture was filtered to separate solid residues out. The solid residues were thoroughly washed with distilled water to neutral $\mathrm{pH}$ and dried in the oven at $105^{\circ} \mathrm{C}$ for $48 \mathrm{~h}$.

2.5. Chemical Analysis Methods. The moisture content of raw material was determined by drying at $105^{\circ} \mathrm{C}$ for $48 \mathrm{~h}$. The chemical composition of oven-dried untreated and pretreated raw material was analyzed following the National Renewable Energy Laboratory (NREL) Chemical Analysis and Testing Standard Procedure. The cellulose and hemicellulose content were determined by the methods of Van Soest et al. [17]. The lignin and starch content were analyzed according to Sluiter et al. [18] and Sluiter and Sluiter [19] in NREL Chemical Analysis and Testing Standard Procedure. The ethanol content was determined using an ethanol assay kit under standard conditions according to the manufacturer's instruction (Megazyme, K-ETOH 01/I4, Ireland). 
Monosaccharide components were quantified by highperformance liquid chromatography (HPLC; Shimadzu corp. Kyoto, Japan), with a refractive index detector (Shimadzu RID-10A) on a CLC- $\mathrm{NH}_{2}(\mathrm{M}) 25 \mathrm{~cm}$ operated at room temperature. These analytical values are shown as the means of duplicate experiments. Scanning electron microscopy (SEM) (FEI inspect-500) was employed to investigate the morphological properties untreated and treated raw material. The specimen for SEM was prepared by Au-Pd coating.

2.6. Enzymatic Hydrolysis. The treated raw material was hydrolyzed using a commercial complex cellulase (Cellic Ctec2, Novozyme, Denmark) and supplemented with complex hemicellulase Cellic Htec2 (Novozyme, Denmark). Cellic Ctec2 activity was estimated as 168,18 FPU/ml enzyme per gram substrate according to the filter paper assay [20] using National Renewable Energy Laboratory (NREL) Chemical Analysis and Testing Standard Procedure. The xylanase activity of Cellic Htec2 was estimated as 110 units/ $\mathrm{ml}$ according to the assay method of Bailey [21]. Enzymatic digestibility of treated raw material was performed at $50^{\circ} \mathrm{C}$ with shaking $120 \mathrm{rpm}$ in a $250 \mathrm{ml}$ flask containing $5 \%(\mathrm{w} / \mathrm{v})$ treated raw material, in the presence of $50 \mathrm{mM}$ sodium acetate buffer $(\mathrm{pH} \mathrm{5)}$ with a working volume of $10 \mathrm{ml}$. The reaction was initiated by mixing $31.65 \mathrm{FPU} / \mathrm{ml}$ of Cellic Ctec2 and 1.6 units/ml of Cellic Htec2 per gram substrate. The released reducing sugar concentration was analyzed based on the amount of liberated reducing sugars using 3,5dinitrosalicylic acid (DNS) method [22].

\subsection{Microorganism and Inoculum Preparation.} Hexose-utilizing yeast, Saccharomyces cerevisiae NCYC 479, and pentose-utilizing yeast, Pichia stipitis NCYC 1541, were obtained from National Collection of Yeast Culture (NCYC), Norwich, UK. The culture was maintained at $4^{\circ} \mathrm{C}$ on a yeast peptone dextrose agar consisting of yeast extract, $10 \mathrm{gl}^{-1}$; peptone $20 \mathrm{gl}^{-1}$; glucose $20 \mathrm{gl}^{-1}$, and agar, $15 \mathrm{gl}^{-1}$ at $\mathrm{pH}$ 5.0. Cells were grown in $150 \mathrm{ml}$ Erlenmeyer flask containing $50 \mathrm{ml}$ of YPD medium (1\% yeast extract, $2 \%$ peptone, and $2 \%$ glucose) in a shaker incubator at $30^{\circ} \mathrm{C}$ with $100 \mathrm{rpm}$. Following $20 \mathrm{~h}$ growth, the broth was centrifuged and inoculum was prepared corresponding to $1.0 \mathrm{gl}^{-1}$ cells.

2.8. Optimization of Ethanol Fermentation. The experimental design and statistical analysis of fermentation were performed according to the RSM using Design-Expert software Version 7.1.5, Stat-Ease, Minneapolis, 2008. Central Composite Design (CCD) [23] was employed to study the combined effect of three independent variables: temperature $\left(X_{1}\right)$, fermentation time $\left(X_{2}\right)$, and cell ratio of $S$. cerevisiae and $P$. stipitis $\left(X_{3}\right)$. RSM experimental design for ethanol fermentation parameters optimization contains a lower and higher level of variables, that is, temperature $(25,30$, and $\left.35^{\circ} \mathrm{C}\right)$, fermentation time $(3,5$, and 7 days), and cell ratio of S. cerevisiae and P. stipitis (0.25:0.75, $0.50: 0.50,0.75: 0.25)$. The dependent variable selected for this study was ethanol concentration $\left(Y_{1}\right)$ and efficiency fermentation $\left(Y_{2}\right)$. In the $\mathrm{CCD}$, the total number of experimental combinations was $2^{K}+2 K+n_{0}$, where $K$ is the number of independent variables and $n_{0}$ is the number of repetitions of the experiments at the center point, which indicated that 20 experiments were required for this procedure. The CCD contains a total of 20 experiments with five-level full factorial design and replications of the central points and axial points (Table 1). The divergences for each factor assessed were split into linear, quadratic, and interactive components and represented using the second-order polynomial function:

$$
\begin{aligned}
Y= & b_{0}+b_{1} X_{1}+b_{2} X_{2}+b_{3} X_{3}+b_{12} X_{1} X_{2}+b_{13} X_{1} X_{3} \\
& +b_{23} X_{2} X_{3}+b_{11} X_{12}+b_{22} X_{22}+b_{33} X_{32},
\end{aligned}
$$

where $Y$ is the predicted response variable; $X_{1}, X_{2}, X_{3}$ are independent variables; $b_{0}$ is the offset term; $b_{1}, b_{2}, b_{3}$ are linear effects; $b_{12}, b_{13}, b_{23}$ are interaction terms; and $b_{11}, b_{22}$, $b_{33}$ are squared effects. The significance of all terms in the polynomial functions was assessed statistically using F-value at a probability $(P)$ of 0.05 . The regression coefficients were then used to generate contour maps from the regression models. Validation was performed after the optimum fermentation condition for ethanol fermentation was obtained.

\section{Results and Discussion}

3.1. Separation of Vascular Bundle and Parenchyma. Separation of the vascular bundle (VB) and parenchyma (PA) of oil palm trunks was performed by cutting, size reduction, pressing, drying, and sieving. According to Darwis et al. [24], the vascular bundle has a higher density in the central part than the bottom of oil palm trunks. The chemical composition of palm trunks after 30 mesh $(595 \mu \mathrm{m})$ sieving is presented in Table 2.

Further sieving by using 80 mesh $(177 \mu \mathrm{m})$ was performed to separate starch from VB. Noor et al. [25] stated that the starch palm trunks size approximately $14.5 \mu \mathrm{m}$. By further sieving ( 80 mesh), it is expected that starch will be eliminated. The chemical composition after 80 mesh $(177 \mu \mathrm{m})$ sieving is presented in Table 3.

It was found that the level of lignin and cellulose was higher in $\geq 177 \mu \mathrm{m}$ particles than in particles which have sizes less than $177 \mu \mathrm{m}$. Thus, it is assumed that particle that did not pass in 80 mesh sieving is VB with high cellulose content. However, it still contained starch about 20.19\%, which may decrease the effectiveness of delignification. Delignification in this study was done chemically and physically (heating). The effectiveness of delignification will decrease due to starch gelatinization, which occurs during heat treatment. The gelatinization temperature of palm starch is $52.4-72.1^{\circ} \mathrm{C}$ [25]. To solve this problem, enzymatic hydrolysis using $\alpha$-amylase is selected to be applied to decrease starch content in the preparation of raw material prior to delignification [26, 27]. Table 4 shows the chemical composition of raw material after enzymatic hydrolysis.

Hydrolysis treatment led to a reduction in lignin and starch while an increase in cellulose and hemicellulose. 
TABLE 1: Optimization experiment design and ethanol production performance of S. cerevisiae and P. stipitis coculture by simultaneous saccharification and cofermentation (SSCF).

\begin{tabular}{|c|c|c|c|c|c|c|c|c|}
\hline \multirow{2}{*}{ No. } & \multirow{2}{*}{ Temperature $\left({ }^{\circ} \mathrm{C}\right)$} & \multirow{2}{*}{ Fermentation time (days) } & \multirow{2}{*}{$\begin{array}{l}\text { Cell } \\
\text { ratio }\end{array}$} & \multicolumn{3}{|c|}{ Variable } & \multirow{2}{*}{$\begin{array}{l}\text { Ethanol }(\% \mathrm{v} / \\
\text { v) }\left(Y_{1}\right)\end{array}$} & \multirow{2}{*}{ Fermentation efficiency $(\%)\left(Y_{2}\right)$} \\
\hline & & & & $X_{1}$ & $X_{2}$ & $X_{3}$ & & \\
\hline 1 & 35 & 7 & 0.75 & +1 & +1 & +1 & 1.34 & 30.03 \\
\hline 2 & 35 & 7 & 0.25 & +1 & +1 & -1 & 0.87 & 18.61 \\
\hline 3 & 35 & 3 & 0.75 & +1 & -1 & +1 & 1.50 & 62.63 \\
\hline 4 & 35 & 3 & 0.25 & +1 & -1 & -1 & 1.45 & 49.21 \\
\hline 5 & 25 & 7 & 0.75 & -1 & +1 & +1 & 1.34 & 40.16 \\
\hline 6 & 25 & 7 & 0.25 & -1 & +1 & -1 & 0.64 & 19.18 \\
\hline 7 & 25 & 3 & 0.75 & -1 & -1 & +1 & 0.67 & 24.17 \\
\hline 8 & 25 & 3 & 0.25 & -1 & -1 & -1 & 0,58 & 20.99 \\
\hline 9 & 38 & 5 & 0.50 & +1.682 & 0 & 0 & 0.88 & 69.46 \\
\hline 10 & 22 & 5 & 0.50 & -1.682 & 0 & 0 & 1.34 & 46.50 \\
\hline 11 & 30 & 8 days, $10 \mathrm{~h}$ & 0.50 & 0 & +1.682 & 0 & 0.78 & 22.41 \\
\hline 12 & 30 & 1 day, $15 \mathrm{~h}$ & 0.50 & 0 & -1.682 & 0 & 0.82 & 53.43 \\
\hline 13 & 30 & 5 & 0.92 & 0 & 0 & +1.682 & 1.25 & 36.42 \\
\hline 14 & 30 & 5 & 0.08 & 0 & 0 & -1.682 & 0.78 & 22.53 \\
\hline 15 & 30 & 5 & 0.50 & 0 & 0 & 0 & 2.18 & 63.20 \\
\hline 16 & 30 & 5 & 0.50 & 0 & 0 & 0 & 1.77 & 51.32 \\
\hline 17 & 30 & 5 & 0.50 & 0 & 0 & 0 & 1.84 & 53.36 \\
\hline 18 & 30 & 5 & 0.50 & 0 & 0 & 0 & 2.25 & 65.24 \\
\hline 19 & 30 & 5 & 0.50 & 0 & 0 & 0 & 1.89 & 55.20 \\
\hline 20 & 30 & 5 & 0.50 & 0 & 0 & 0 & 2.00 & 57.99 \\
\hline
\end{tabular}

TABLE 2: Chemical composition analysis of raw material after 30 mesh sieving.

\begin{tabular}{lccccc}
\hline Compound & Weight $(\mathrm{g})$ & Lignin $(\% \mathrm{~b} / \mathrm{b})$ & Cellulose $(\% \mathrm{~b} / \mathrm{b})$ & Hemicellulose $(\% \mathrm{~b} / \mathrm{b})$ & Starch $(\% \mathrm{~b} / \mathrm{b})$ \\
\hline$\geq 595 \mu \mathrm{m}$ & 36 & 19.40 & 33.90 & 14.30 & 25.18 \\
$\leq 595 \mu \mathrm{m}$ & 64 & 18.58 & 30.21 & 14.52 & 35.00 \\
\hline
\end{tabular}

TABLE 3: Chemical composition analysis of raw material after 80 mesh sieving.

\begin{tabular}{lccccc}
\hline Compound & Weight $(\mathrm{g})$ & Lignin $(\% \mathrm{~b} / \mathrm{b})$ & Cellulose $(\% \mathrm{~b} / \mathrm{b})$ & Hemicellulose $(\% \mathrm{~b} / \mathrm{b})$ & Starch $(\% \mathrm{~b} / \mathrm{b})$ \\
\hline$\geq 177 \mu \mathrm{m}$ & 26 & 22.49 & 41.13 & 14.20 & 20.19 \\
$\leq 177 \mathrm{um}$ & 74 & 19.06 & 28.19 & 14.70 & 36.84 \\
\hline
\end{tabular}

TABLE 4: Chemical composition analysis of raw material after enzymatic hydrolysis.

\begin{tabular}{lccccc}
\hline Treatment & Weight $(\mathrm{g})$ & Lignin $(\% \mathrm{~b} / \mathrm{b})$ & Cellulose $(\% \mathrm{~b} / \mathrm{b})$ & Hemicellulose $(\% \mathrm{~b} / \mathrm{b})$ & Starch $(\% \mathrm{~b} / \mathrm{b})$ \\
\hline Before hydrolysis & 100 & 22.49 & 41.13 & 14.20 & 20.19 \\
After hydrolysis & 72,27 & 17.73 & 51.45 & 16.63 & 12.24 \\
\hline
\end{tabular}

Starch has been reduced to $29.47 \%$, while cellulose and hemicelluloses have been increased until $8.51 \%$ and $5.28 \%$, respectively.

3.2. Delignification. There are three methods of delignification, which were applied to the lignocellulosic palm trunks, which were alkali and heat treatment $(\mathrm{NaOH} 5 \% \mathrm{w} / \mathrm{v}$, oven $150^{\circ} \mathrm{C}$ for 3 hours); alkali-microwave ( $\mathrm{NaOH} 5 \% \mathrm{w} / \mathrm{v}, 400$ watts for $30 \mathrm{~min})$; and alkaline peroxide and heat treatment $(\mathrm{NaOH}$ $5 \% \mathrm{w} / \mathrm{v}, 121^{\circ} \mathrm{C}$ for 15 minutes). Alkaline conditions were chosen because of their advantages which include the following: (1) impact on the degradation of sugars smaller when compared to the delignification in acidic conditions, (2) ability to dissolve the lignin greater than in acidic conditions, and (3) a small effect on the crystallinity of cellulose [28, 29]. The comparison of lignin content before and after delignification is presented in Table 5.
The result shows that the combination of alkali and heat treatment did not cause a significant lignin reduction, as well as in the alkali treatment with microwave. A significant lignin reduction $(80.88 \%)$ was found in alkaline peroxide and heat treatment. By this pretreatment, the complex matrix is destroyed, and the enzymes' access to the carbohydrates is facilitated. Senila et al. [30] reported that the solid yields for the used autohydrolysis pretreatments were found to be between 62.2 and $71.0 \%\left(165^{\circ} \mathrm{C}\right)$ and 52.3 and $64.3 \%$ $\left(180^{\circ} \mathrm{C}\right)$, respectively. Figure 1 shows the physical change of raw materials before and after delignification.

Figure 1 provides an insight into the variation structure change affected by some methods of pretreatment. Alkali treatment with a hot oven causes physical changes in the surface (Figures 1(a) and 1(b)). The lignocellulose surface of the bulge-shaped section contains an accumulation of lignin [31]. Figure 1(b) shows that lignin has been degraded in the lignocellulosic surface. Gould et al. 
TABLE 5: The lignin content before and after delignification.

\begin{tabular}{lc}
\hline Treatment & Lignin $(\% \mathrm{w} / \mathrm{w})$ \\
\hline 1. Control & 17.73 \\
2. Alkali and heat treatment & 18.76 \\
3. Microwave-alkali treatment & 18.23 \\
4. Alkaline peroxide and heat treatment & 3.39 \\
\hline
\end{tabular}

[31] and Kumar and Sharma [32] also explained that lignin is a compound that glue the vessels and restrict file microfibril cellulose in plant cell walls. A thin layer between cellulose microfibrils also is a complex of lignin and hemicellulose. Figure 1(c) shows that microwaves-alkali treatment led to the degradation heat penetration because the interaction of microwaves with water molecules is higher than the heat penetration of a hot oven. Physical changes of raw materials after delignification with alkaline peroxide and heat treatment (1D) differ significantly from the condition of raw materials before treatment (Figure 1(a)). Figure 1(d) shows that alkaline peroxide and heat treatment caused the degradation of lignin in the surface as well as between the cellulose microfibrils more leverage than the treatment of alkali with a hot oven or by microwaves $[4,33]$. It is proven that cellulose microfibrils have successfully broken down. Singh et al. [29] also explained that the removal of lignin causes cell separation vessel beam, thus forming the cellular structure are linked to each other long in the longitudinal direction. Lignin decomposition may occur due to rupture $\alpha$-aryl ether bond of monomer polyphenols constituent lignin. Therefore, treatment with hot alkaline peroxide delignification was chosen as the appropriate method to be applied to lignocellulose palm trunks. The advantages of alkaline peroxide delignification method with heat treatment do not require high pressure and expensive equipment and can significantly degrade lignin [34]. Changes in the chemical composition of raw materials after delignification with alkaline peroxide and heat treatment $\left(121^{\circ} \mathrm{C}, 1 \mathrm{~atm}, 15\right.$ minutes $)$ are presented in Table 6.

Table 6 explains that alkaline peroxide decreased lignin content to $3.39 \%$ and reduced hemicellulose content to $10.41 \%$. In addition, alkaline peroxide increased cellulose content to $72.42 \%$, suggesting that cellulose is readily hydrolyzed into sugars. Singh et al. [29] stated that the acetyl group is a side chain of the main structure of xylan. The removal of acetyl groups from the raw materials can improve the accessibility of the enzyme to cellulose and xylan. Table 7 shows the effect of alkaline peroxide and heat treatment on the digestibility of substrate.

Table 7 shows that the content of reducing glucose in raw materials increased significantly (93.22\%) after delignification. Lignin reduction was also observed to $3.39 \%$. It was confirmed that the lignin reduction was a success and led to increasing the accessibility of cellulase to the substrate. Another study showed that alkaline pretreatment was conducted on sugarcane bagasse, reducing lignin content by $7.16 \%$ [35]. Furthermore, Aguirre-Fierro et al. [36] applied a high-pressure
$\mathrm{CO}_{2}-\mathrm{H}_{2} \mathrm{O}$ mixture at various temperatures yielding $75.8 \mathrm{~mol} \%$ of the polysaccharides present in bagasse. The combined effect of steam exploded, and acid hydrolysis was performed to obtain the high reducing sugar $(77 \mathrm{~g} / \mathrm{L})$ [37].

3.3. Optimization of Ethanol Production Efficiency. The results presented in Table 1 revealed the 20 combinations along with their responses in terms of final ethanol production and fermentation efficiency. Among the 20 RSM combinations, maximum ethanol production was achieved in the combination of fermentation condition at $30^{\circ} \mathrm{C}, 5$ days incubation with the same cell ratio at 0.5:0.5 (S. cerevisiae and P. stipitis). Saccharification and cofermentation simultaneously were performed preceded by prehydrolysis, which was conducted at $50^{\circ} \mathrm{C}$ for 8 hours. Prehydrolysis intended for fermentation can be initiated on the condition of the substrate and the yeast mix well [38]. Prehydrolysis processes were evaluated based on the changes of the physical substrate and sugar content. Inoculation of yeast into the substrate was performed after the substrate achieved a sugar content that can be used to initiate the fermentation. Cell ratio of $S$. cerevisiae/P. stipitis, culture temperature, and fermentation time were analyzed to determine its relationship to the response prior to the optimization stage [39]. The optimization stage was done after the independent and dependent variables proved to have a quadratic relationship [40]. Optimization of saccharification and cofermentation was done based on the central composite design response surface method. Data experimental results were analyzed using the Design-Expert program to predict regression (statistical model) response data. The independent variables, that is, cell ratio, temperature, and fermentation time, were optimized, whereas the observed response is ethanol and fermentation efficiency. The efficiency of fermentation is an additional response, which is the development of content data of ethanol. Fermentation efficiency value was calculated based on the concentration of ethanol divided by glucose levels change until the end of fermentation ( $\Delta$ substrate) and multiplied by $100 \%$. Optimization experiment design and ethanol production performance of $S$. cerevisiae and P. stipitis coculture are presented in Table 1.

Statistical model in Software Design Expert consists of a quadratic model, linear, 2FI (interaction of two factors), and cubic [41]. Selection of the most appropriate statistical model to determine the optimum response is based on the evaluation order of the sum of squares (sequential model of sum squares), inaccuracies testing model (lack of fit test), and summary statistics (model statistical summary) [40]. Table 8 provides the profile of xylose and glucose of S. cerevisiae/P. stipitis coculture fermentation.

The data were put in equation (1), and the resulting regression second polynomial equations with significant factors for two responses (equations (2) and (3)) are presented below.

The final equation in terms of significant coded factors for ethanol response: 


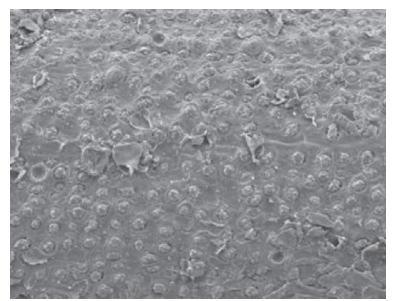

(a)

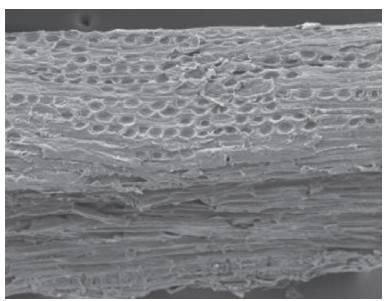

(b)

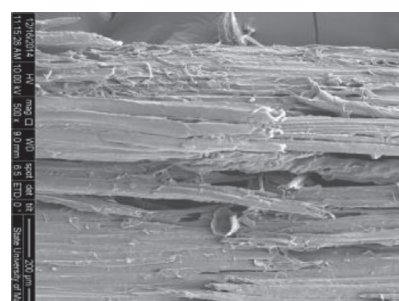

(c)

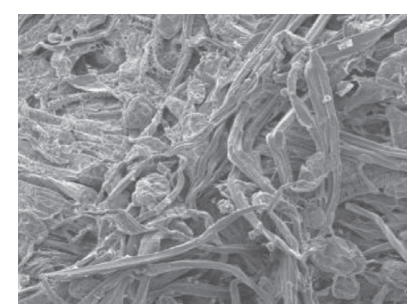

(d)

FiguRE 1: SEM images of untreated raw materials (a); pretreated raw materials with $\mathrm{NaOH} 5 \%, 150^{\circ} \mathrm{C}$ for 3 hour (b); pretreated raw materials with microwave-alkali ( $\mathrm{NaOH} 5 \% \mathrm{w} / \mathrm{v}, 121^{\circ} \mathrm{C}$ for 15 minutes) (c); pretreated raw materials with $\mathrm{H}_{2} \mathrm{O}_{2} 5 \% ; \mathrm{pH} 11.5 ; 121^{\circ} \mathrm{C}$ for 15 min $(\mathrm{d}$ ).

TABLE 6: Chemical composition of raw materials after alkaline peroxide and heat treatment.

\begin{tabular}{lccccc}
\hline Treatment & Weight $(\mathrm{g})$ & Lignin $(\% \mathrm{~b} / \mathrm{b})$ & Cellulose $(\% \mathrm{~b} / \mathrm{b})$ & Hemicellulose $(\% \mathrm{~b} / \mathrm{b})$ & Starch $(\% \mathrm{~b} / \mathrm{b})$ \\
\hline Before & 100 & 17.73 & 51.45 & 16.63 & 12.24 \\
After & 40 & 3.39 & 72.42 & 10.41 & 12.21 \\
\hline
\end{tabular}

TABLE 7: Effect of alkaline peroxide and heat treatment on reducing sugar.

\begin{tabular}{lccc}
\hline Treatment & Lignin $(\% \mathrm{w} / \mathrm{w})$ & Reducing sugar ${ }^{*}(\% \mathrm{w} / \mathrm{v})$ & Increasing of reducing sugar $(\%)$ \\
\hline Before delignification & 17.73 & 0.36 & 93.22 \\
After delignification & 3.39 & 5.31 & 9 \\
\hline
\end{tabular}

${ }^{*}$ Hydrolysis of $5 \%(\mathrm{~b} / \mathrm{v})$ substrate, with $10 \mathrm{ml}$ working volume using cellulose (Cellic Ctec2) $31.65 \mathrm{FPU} / \mathrm{ml}$ enzyme, $\mathrm{pH}$ buffer 5 , at $50^{\circ} \mathrm{C}$ for $72 \mathrm{~h}$.

$$
\begin{aligned}
Y_{1}(\text { ethanol })= & -15.20+0.80 X_{1}+1.40 X_{2}+5.19 X_{3} \\
& -0.02 X_{1} X_{2}-0.03 X_{1} X_{3}+0.26 X_{2} X_{3} \\
& -0.01 X_{1}^{2}-0.10 X_{2}^{2}-5.05 X_{3}^{2}
\end{aligned}
$$

The final equation in terms of significant coded factors for fermentation efficiency response:

$$
\begin{aligned}
Y_{2}(\text { fermentation efficiency })= & -265.40+9.87 X_{1}+44.90 X_{2} \\
& +185.18 X_{3}-0.97 X_{1} X_{3} \\
& +3.95 X_{2} X_{3}-0.06 X_{12} \\
& -2.16 X_{2}^{2} 185.78 X_{3}^{2} .
\end{aligned}
$$

$X_{1}, X_{2}$, and $X_{3}$ are the code value of the tested variables: temperature, fermentation time, and cell ratio.

\subsection{Effect of Temperature and Fermentation Time on Ethanol} Production. Figure 2 shows the quadratic interaction between temperature and fermentation time for the ethanol response and indicates that temperature up to $32.5^{\circ} \mathrm{C}$ and fermentation time up to 5 days result in the production of high ethanol levels.

Temperature higher than $32.5^{\circ} \mathrm{C}$ and lower than $25^{\circ} \mathrm{C}$ leads to low ethanol production. This result is in accordance with Lin et al. [42] that found the optimum temperature of S. cerevisiae was $30-40^{\circ} \mathrm{C}$ for ethanol production. High temperatures approaching $40^{\circ} \mathrm{C}$ can interfere with transport activity in cells resulting in the production of ethanol decrease. In contrast, $S$. cerevisiae growth rate will decrease under $25^{\circ} \mathrm{C}$ due to low cell tolerance to ethanol [42]. Figure 2 also describes a quadratic relationship between the fermentation time toward ethanol production. The optimum ethanol production could be achieved for 5-day fermentation and decreased after 7-day fermentation. The decrease in ethanol content, along with the increase in fermentation time, is thought to be because ethanol is used by yeast as a carbon source [42].

3.5. Effect of Temperature and Cell Ratio on Ethanol Production. A quadratic relationship was found between the cell ratio and ethanol production of S. cerevisiae/P. stipitis in the simultaneous saccharification and cofermentation (SSCF) process. The high ethanol production $(1.66 \%, \mathrm{v} / \mathrm{v})$ was achieved at cell ratio $S$. cerevisiae/P. stipitis of 0.50 , and temperature of $30^{\circ} \mathrm{C}$, for 3-day fermentation (Figure 3).

The cell ratio at a certain temperature significantly affected the amount of carbon source consumed by S. cerevisiae and P. stipitis, so it can affect the amount of ethanol content [39]. When cell ratio is $0.50: 0.50$ at $30^{\circ} \mathrm{C}$ for 5-day fermentation, S. cerevisiae and Pichia stipitis together actively utilize xylose and glucose as shown in Table 8. Xylose content decreased from $0.626 \%$ (v/v) to $0 \%$ and glucose content decreased from $6.163 \%$ to $0.0027 \%$. When the cell ratio of S. cerevisiae was 0.75 at $35^{\circ} \mathrm{C}$ and $7-$ day fermentation, ethanol concentration reached $1.34 \%$ $(\mathrm{v} / \mathrm{v})$. In this condition, xylose content decreased from $1.062 \%(\mathrm{v} / \mathrm{v})$ to $0.694 \%(\mathrm{v} / \mathrm{v})$, suggesting that a higher consumption rate of glucose was performed by $S$. cerevisiae whereas $P$. stipitis could not consume the xylose maximally. 
TABLe 8: Xylose and glucose content of S. cerevisiae/P. stipitis simultaneous saccharification and cofermentation (SSCF) process.

\begin{tabular}{|c|c|c|c|c|c|c|c|c|c|c|c|c|}
\hline \multirow{3}{*}{ No. } & \multirow{2}{*}{$\begin{array}{l}\text { Temp } \\
\left({ }^{\circ} \mathrm{C}\right)\end{array}$} & \multirow{2}{*}{$\begin{array}{l}\text { Fermentation } \\
\quad \text { (day) }\end{array}$} & \multirow{2}{*}{\multicolumn{2}{|c|}{$\begin{array}{l}\text { Cell } \\
\text { ratio }\end{array}$}} & \multicolumn{5}{|c|}{$\begin{array}{l}\text { Simultaneous saccharification and } \\
\text { cofermentation }\end{array}$} & \multirow{3}{*}{$\begin{array}{c}\Delta \\
\text { substrate }\end{array}$} & \multirow{2}{*}{ Ethanol (\%) } & \multirow{2}{*}{$\begin{array}{l}\text { Fermentation efficiency } \\
(\%)\end{array}$} \\
\hline & & & & & Before & & & After & & & & \\
\hline & & & & Xylose & Glucose & Total & Xylose & Glucose & Total & & & \\
\hline 1 & 35 & 7 & $\begin{array}{c}0.75: \\
0.25\end{array}$ & 1.062 & 8.435 & 9.497 & 0.694 & 0.054 & 0.748 & 8.749 & 1.34 & 30,03 \\
\hline 2 & 35 & 7 & $\begin{array}{c}0.25: \\
0.75\end{array}$ & 1.062 & 8.435 & 9.497 & 0.295 & 0.037 & 0.332 & 9.165 & 0.87 & 18,61 \\
\hline 3 & 35 & 3 & $\begin{array}{c}0.75: \\
0.25\end{array}$ & 0.759 & 7.002 & 7.761 & 0.970 & 2.095 & 3.065 & 4.696 & 1.50 & 62,63 \\
\hline 4 & 35 & 3 & $\begin{array}{c}0.25: \\
0.75\end{array}$ & 0.759 & 7.002 & 7.761 & 0.915 & 1.068 & 1.983 & 5.778 & 1.45 & 49,21 \\
\hline 5 & 25 & 7 & $\begin{array}{c}0.75: \\
0.25\end{array}$ & 0.841 & 5.702 & 6.543 & 0.000 & 0.000 & 0.000 & 6.543 & 1.34 & 40,16 \\
\hline 6 & 25 & 7 & $\begin{array}{c}0.25: \\
0.75\end{array}$ & 0.841 & 5.702 & 6.543 & 0.000 & 0.000 & 0.000 & 6.543 & 0.64 & 19.18 \\
\hline 7 & 25 & 3 & $\begin{array}{c}0.75: \\
0.25\end{array}$ & 0.419 & 5.042 & 5.461 & 0.000 & 0.026 & 0.026 & 5.435 & 0.67 & 24,17 \\
\hline 8 & 25 & 3 & $\begin{array}{c}0.25: \\
0.75\end{array}$ & 0.419 & 5.042 & 5.461 & 0.000 & 0.042 & 0.042 & 5.419 & 0.58 & 20,99 \\
\hline 9 & 38 & 5 & $\begin{array}{c}0.50: \\
0.50\end{array}$ & 1.124 & 10.319 & 11.443 & 1.201 & 7.758 & 8.959 & 2.484 & 0.88 & 69,46 \\
\hline 10 & 22 & 5 & $\begin{array}{c}0.50: \\
0.50\end{array}$ & 0.780 & 4.920 & 5.700 & 0.000 & 0.050 & 0.050 & 5.650 & 1.34 & 46,50 \\
\hline 11 & 30 & 8 days, $10 \mathrm{~h}$ & $\begin{array}{c}0.50: \\
0.50\end{array}$ & 0.691 & 6.160 & 6.851 & 0.000 & 0.0027 & 0.027 & 6.824 & 0.78 & 22,41 \\
\hline 12 & 30 & 1 day, $15 \mathrm{~h}$ & $\begin{array}{c}0.50: \\
0.50\end{array}$ & 0.340 & 4.358 & 4.698 & 0.660 & 1.029 & 1.689 & 3.009 & 0.82 & 53,43 \\
\hline 13 & 30 & 5 & $\begin{array}{c}0.92: \\
0.08\end{array}$ & 0.626 & 6.163 & 6.789 & 0.000 & 0.060 & 0.060 & 6.729 & 1.25 & 36,42 \\
\hline 14 & 30 & 5 & $\begin{array}{c}0.08: \\
0.92\end{array}$ & 0.626 & 6.163 & 6.789 & 0.000 & 0.000 & 0.000 & 6.789 & 0.78 & 22,53 \\
\hline 15 & 30 & 5 & $\begin{array}{c}0.50: \\
0.50\end{array}$ & 0.626 & 6.163 & 6.789 & 0.000 & 0.026 & 0.026 & 6.763 & 2.18 & 63,20 \\
\hline 16 & 30 & 5 & $\begin{array}{c}0.50: \\
0.50\end{array}$ & 0.626 & 6.163 & 6.789 & 0.000 & 0.027 & 0.027 & 6.762 & 1.77 & 51,32 \\
\hline 17 & 30 & 5 & $\begin{array}{c}0.50: \\
0.50\end{array}$ & 0.626 & 6.163 & 6.789 & 0.000 & 0.028 & 0.028 & 6.761 & 1.84 & 53,36 \\
\hline 18 & 30 & 5 & $\begin{array}{c}0.50: \\
0.50\end{array}$ & 0.626 & 6.163 & 6.789 & 0.000 & 0.027 & 0.027 & 6.762 & 2.25 & 65,24 \\
\hline 19 & 30 & 5 & $\begin{array}{c}0.50: \\
0.50\end{array}$ & 0.626 & 6.163 & 6.789 & 0.000 & 0.075 & 0.075 & 6.714 & 1.89 & 55,20 \\
\hline 20 & 30 & 5 & $\begin{array}{c}0.50: \\
0.50\end{array}$ & 0.626 & 6.163 & 6.789 & 0.000 & 0.026 & 0.026 & 6.763 & 2.00 & 57,99 \\
\hline
\end{tabular}

3.6. Effect of Fermentation Time and Cell Ratio on Ethanol Production. A quadratic relationship between fermentation time and cell ratio was observed on ethanol production.

Figure 4 shows that ethanol increased by the increase in the cell ratio and then decreased after reaching maximum ethanol content. The same phenomenon was also observed for fermentation time toward ethanol production $[15,16]$.

3.7. Effect of Temperature and Fermentation Time on Fermentation Efficiency. Fermentation efficiency can reach about $60 \%$ at a cell ratio of $0.5,35^{\circ} \mathrm{C}$, and 3 -day fermentation. This result is in accordance with the data shown in Table 1 that shows the fermentation efficiency of about $62.63 \%$ under the cell ratio of S. cerevisiae/P. stipitis at $0.75: 0.25,35^{\circ} \mathrm{C}$, and 3-day fermentation. S. cerevisiae is more active in using glucose than
$P$. stipitis at $35^{\circ} \mathrm{C}$ since glucose consumption occurred during the cofermentation process but not for xylose (Table 8).

However, under the same cell ratio and temperature, the fermentation efficiency decreased to $45 \%$ when longer incubation (7 days) was performed (Figure 5).

The longer the fermentation time is, the lower the ethanol can be produced because ethanol will be consumed by $S$. cerevisiae as a carbon source to generate energy. On the contrary, a longer period of fermentation time will have a toxic effect on the growth of the microorganisms, especially in the batch mode due to the higher concentration of ethanol produced from the system $[43,44]$. This relationship can be explained by analysis of variance (data not shown), which shows that there is a correlation between temperature and fermentation time on the efficiency of fermentation. The value of the correlation coefficient is -0.97 . The negative values 


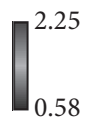

$\mathrm{X} 1$ = A: Temperature $\mathrm{X} 2=\mathrm{B}$ : Fermentation time

Actual Factor

C: Cell ratio $=0.50$

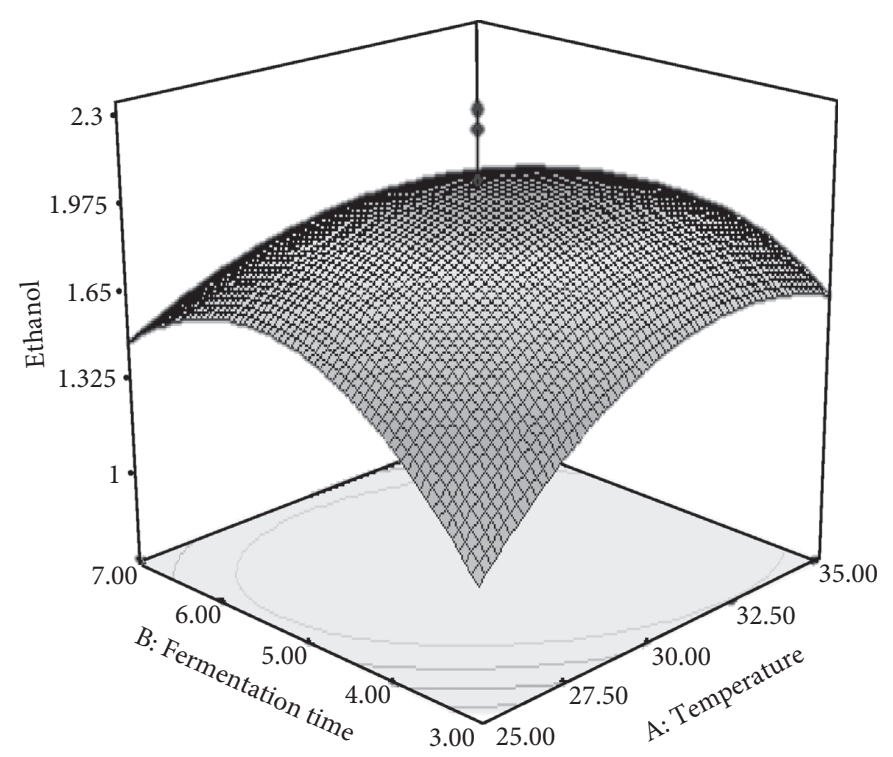

Ethanol

- Design point above predicted value

- Design point above predicted value

Figure 2: 3D surface plot representing the interaction between temperature and fermentation time for the response ethanol by S. cerevisiae/ P. stipitis in the simultaneous saccharification and cofermentation (SSCF) process.

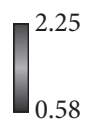

$\mathrm{X} 1=\mathrm{A}:$ Temperature $\mathrm{X} 2$ = C: Cell ratio

Actual Factor

B: Fermentation time $=5.00$

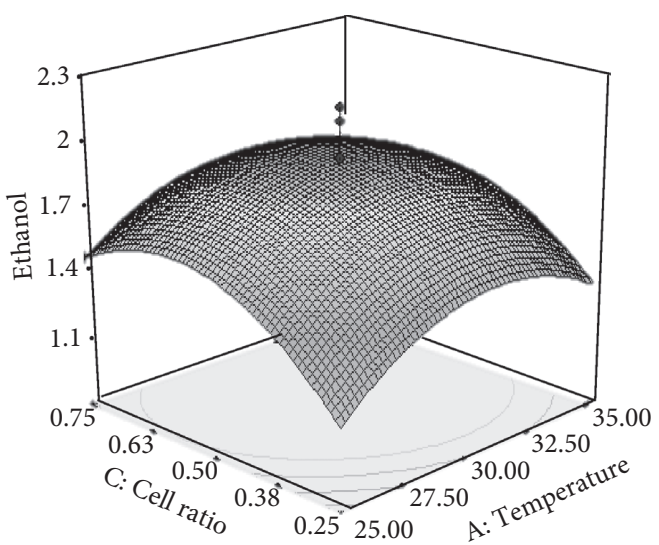

Ethanol

- Design point above predicted value

- Design point above predicted value

FIGURE 3: 3D surface plot representing the interaction between temperature and cell ratio for the response ethanol by $S$. cerevisiae/P. stipitis in the simultaneous saccharification and cofermentation (SSCF) process.

reflect an inverse relationship, meaning that the higher the temperature and the shorter the fermentation time, the more the fermentation efficiency. The result can be explained by the data shown in Table 8 . When the temperature is $35^{\circ} \mathrm{C}$, 3-day fermentation, and cell ratio of $0.75: 0.25$, the fermentation efficiency reaches $62.63 \%$, but when the temperature is $25^{\circ} \mathrm{C}$ and 7-day fermentation, with the same cell ratios, the fermentation efficiency decreases to $40.16 \%$.

\subsection{The Effect of Temperature and Cell Ratio on Fermentation} Efficiency. Figure 6 shows the optimum fermentation efficiency in the range of $30^{\circ} \mathrm{C}$, the cell ratio of $0.50: 0.50$, and 5day fermentation. S. cerevisiae and $P$. stipitis can ferment together at a temperature and duration of fermentation. Results of analysis of variance show that there is no correlation between the ratio of cells with long fermentation on the efficiency of fermentation. However, the type of fermentation method is effected the fermentation efficiency, which fed-batch culture produced resulted in better cell concentration than batch culture did. In contrast, higher concentration of substrate was also found to affect the $\mathrm{pH}$, viscosity, and the activity of the fermentation medium [45].

3.9. Effect of Fermentation Time and Cell Ratio on Fermentation Efficiency. Figure 7 shows that the cell ratio of $0.25: 0.75,3$-day fermentation, and under $30^{\circ} \mathrm{C}$ achieved 


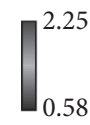

$\mathrm{X} 1=\mathrm{B}$ : Fermentation time $\mathrm{X} 2$ = C: Cell ratio

Actual Factor

A: Temperature $=30.00$

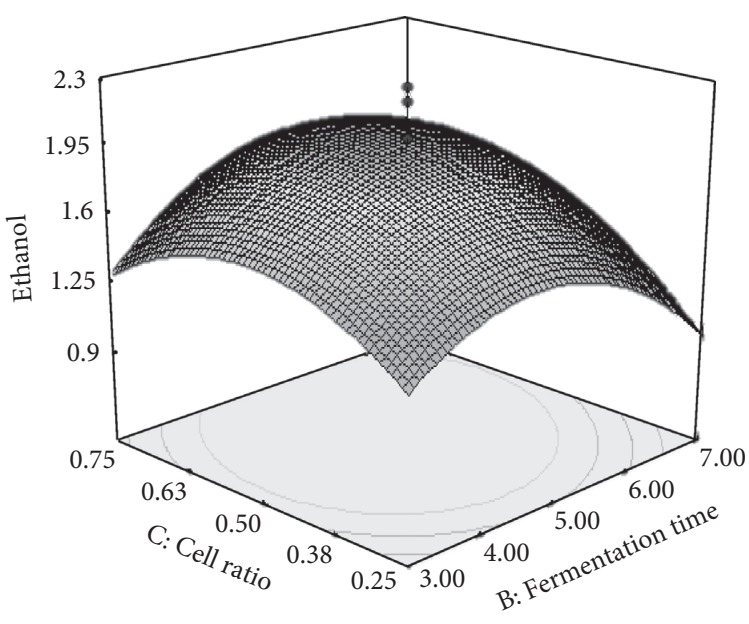

Ethanol

- Design point above predicted value

- Design point above predicted value

FIGURE 4: 3D surface plot representing the interaction between cell ratio and fermentation time for the response ethanol by $S$. cerevisiae/P. stipitis in the simultaneous saccharification and cofermentation (SSCF) process.

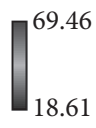

$\mathrm{X} 1=\mathrm{A}:$ Temperature $\mathrm{X} 2$ = B: Fermentation time

Actual Factor

C: Cell ratio $=0.50$

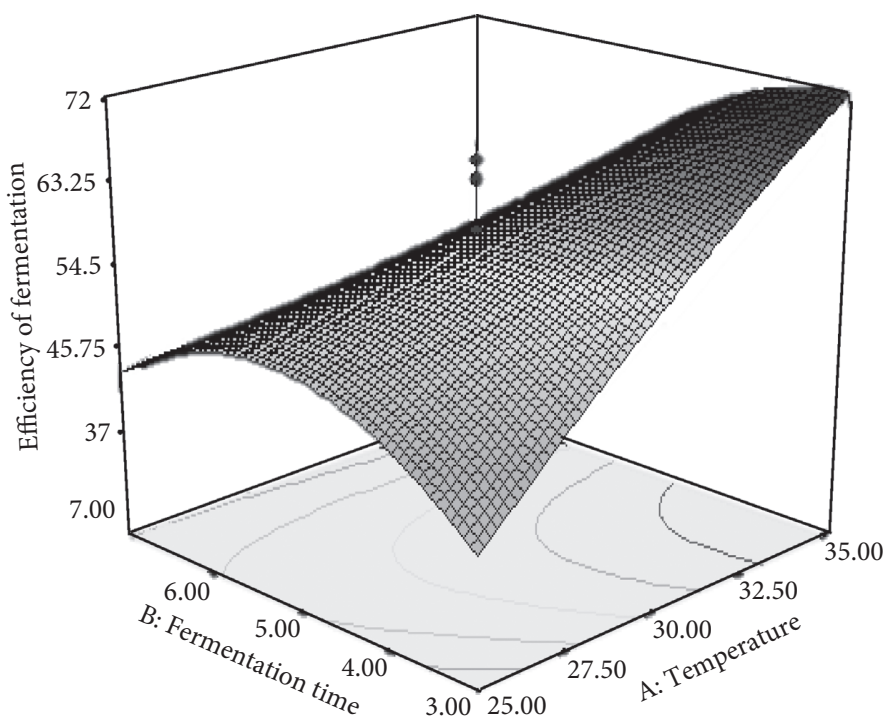

Efficiency of fermentation

- Design point above predicted value

- Design point above predicted value

FIGURE 5: 3D surface plot representing the interaction between temperature and fermentation time for the response fermentation efficiency by S. cerevisiae/P. stipitis in simultaneous saccharification and cofermentation (SSCF) process.

fermentation efficiency of about $41.5 \%$. When the cell ratio is $0.50: 0.50$, fermentation efficiency increases to $54 \%$ and decreases to $50 \%$ when the cell ratio is $0.75: 0.25$. These data illustrate the quadratic relationship between the cell ratio and the efficiency of fermentation. The quadratic relationship is also found between fermentation time and fermentation efficiency. Fermentation efficiency reached 39\%, 3-day fermentation, $30^{\circ} \mathrm{C}$, cell ratio of $0.25: 0.75$; increased to $47 \%$ for 5 -day fermentation; and decreased to approximately $25 \%$ for 7 -day fermentation.
3.10. Validation for Optimal Simultaneous Saccharification and Cofermentation of Ethanol. Optimization of saccharification and cofermentation simultaneously (SSCF) temperature treatment, fermentation time, and cell ratio were statistically analyzed using Design-Expert software, version 7. The model predicted the optimal conditions as follows: cell ratio of $S$. cerevisiae/P. stipitis at 0.54 ; temperature at $33.45^{\circ} \mathrm{C}$; and fermentation time at 4.22 days. The maximum yield prediction on ethanol and fermentation efficiency under optimal conditions is shown in Table 9. 

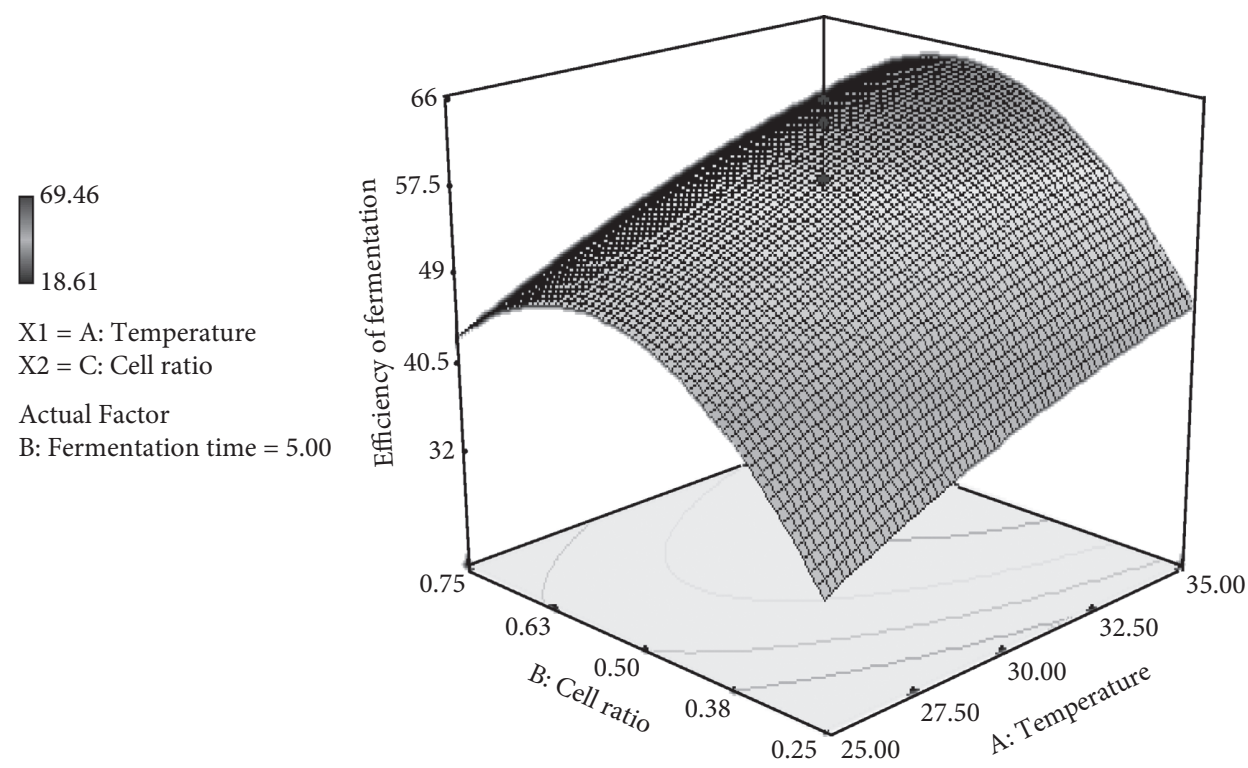

Efficiency of fermentation

- Design point above predicted value

- Design point above predicted value

FiguRE 6: 3D surface plot representing the interaction between cell ratio and temperature for the response fermentation efficiency by S. cerevisiae/P. stipitis in the simultaneous saccharification and cofermentation (SSCF) process.

$\prod_{18.61}^{69.46}$
$\mathrm{X} 1=$ A: Fermentation time
$\mathrm{X} 2=$ C: Cell ratio
Actual Factor
C: Temperature $=30.00$

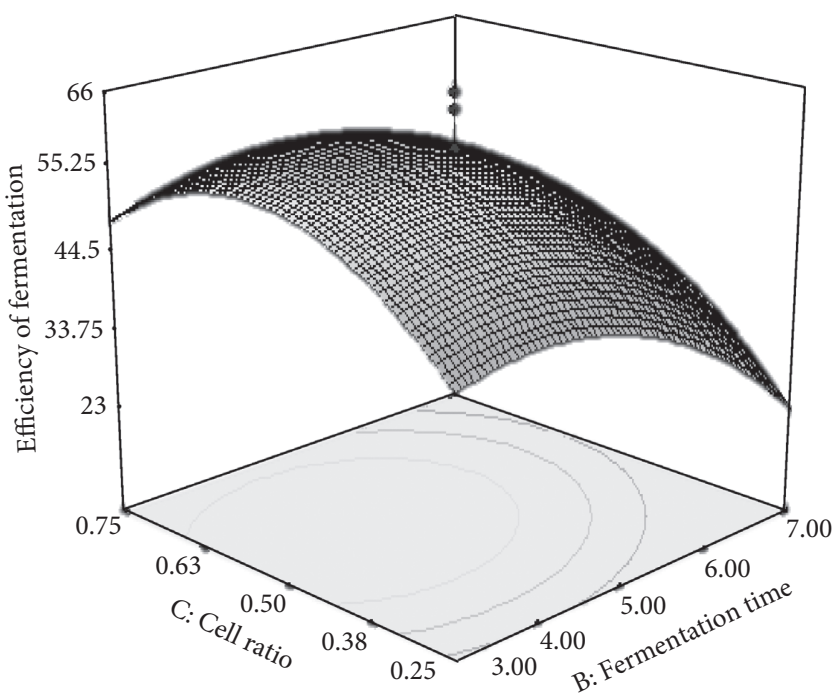

Efficiency of fermentation

- Design point above predicted value

- Design point above predicted value

FIGURE 7: 3D surface plot representing the interaction between cell ratio and fermentation time for the response fermentation efficiency by S. cerevisiae/P. stipitis in the simultaneous saccharification and cofermentation (SSCF) process.

The optimal condition at temperature of $33.45^{\circ} \mathrm{C}$, fermentation time of 4.22 days, and cell ratio of $S$. cerevisiae at 0.54 are chosen by the program based on the levels of ethanol fermentation and highest efficiency. Validation is done by comparing the response of the actual experimental results with the predicted value of the program. The suitability of variables at the optimal point is tested and repeated three times based on temperature variables $33.45^{\circ} \mathrm{C}, 4.22$ days, and cell ratio of $S$. cerevisiae at 0.54 . Validation shows that the difference between actual experimental results and the predicted value of the program Design-Expert of ethanol content is $1.22 \%$ and $0.72 \%$ for fermentation efficiency (Table 10).

The differences between the experimental value and predicted value were found to be less than $5 \%$, indicating the value of the independent variables' optimal point is quite suitable to produce an optimal response. Sun et al. [46] reported that the results of the experimental validation and 
TABle 9: Optimization predicted by Design-Expert program.

\begin{tabular}{lcc}
\hline Response & Optimum point of SSCF under optimal conditions $\left(33,45^{\circ} \mathrm{C}, 4,22\right.$ days and cell ratio of S. cerevisiae 0,54$)$ \\
\hline Ethanol $(\%, \mathrm{v} / \mathrm{v})$ & 1,905 \\
Fermentation efficiency & 66,628 \\
\hline
\end{tabular}

TABLE 10: Experimental validation.

\begin{tabular}{lccccccc}
\hline & Variables of SSCF & \multicolumn{3}{c}{ Ethanol (\%) } & \multicolumn{3}{c}{ Fermentation efficiency (\%) } \\
Temperature $\left({ }^{\circ} \mathrm{C}\right)$ & Fermentation time (days) & Cell ratio & Experiment & Predicted & $\%$ Difference & Experiment & Predicted \\
$\%$ Difference \\
\hline 33,45 & 4,22 & 0,54 & 1,87 & 1,91 & 2,09 & 65,91 & 66,62 \\
33,45 & 4,22 & 0,54 & 1,90 & 1,91 & 0,52 & 66,14 & 66,62 \\
33,45 & 4,22 & 0,54 & 1,89 & 1,91 & 1,05 & 66,37 & 66,62 \\
Average & & & 1,89 & 1,91 & 1,22 & 66,14 & 66,62 \\
\hline
\end{tabular}

predictive value of the program have an error rate of less than $5 \%$, proving that the value of the optimum point variables has high suitability.

\section{Conclusion}

The SSCF process by $S$. cerevisiae and $P$. stipitis was systematically optimized using a design experiment. Alkaline peroxide combined with heat treatment successfully removed lignin until $93.22 \%$ of the treated oil palm trunk. Optimization of SSCF condition using the Doe model show that the coculture can work together to produce maximum ethanol and fermentation efficiency at $33,45^{\circ} \mathrm{C}, 4.22$ days, and cell ratio of 0.54:0.46 (S. cerevisiae NCYC 479 and $P$. stipitis NCYC 1541). This study could provide a strategy for the improvement of efficient ethanol production in the SSCF process of the oil palm trunk.

\section{Data Availability}

The data used to support the findings of this study are included within the article.

\section{Conflicts of Interest}

The authors declare no conflicts of interest.

\section{Authors' Contributions}

Agustin Krisna Wardani, Aji Sutrisno, and Untung Murdiyatmo conceived the idea and plan of this project. Titik Nur Faida performed the fermentation and analysis. Aji Sutrisno performed part of the experiments in enzymatic treatments of raw materials. Retno Dwi Yustina provided the raw material and performed pretreatment of raw materials. Agustin Krisna Wardani supervised the whole research and reviewed and edited the manuscript. All the authors read and approved the final manuscript.

\section{Acknowledgments}

The authors are grateful to PT Sampoerna Agro Tbk. Indonesia for their financial support in conducting this work.

\section{References}

[1] P. Manzanares, "The role of biorefinering research in the development of a modern bioeconomy," Acta Innovations, vol. 37, no. 37, pp. 47-56, 2020.

[2] S. Gajula and C. R. K. Reddy, "More sustainable biomass production and biorefining to boost the bioeconomy," Biofuels, Bioproducts \& Biorefining, 2021.

[3] Y. Shigetomi, Y. Ishimura, and Y. Yamamoto, "Trends in global dependency on the Indonesian palm oil and resultant environmental impacts," Scientific Reports, vol. 10, no. 1, Article ID 20624, 2020.

[4] K. Kucharska, I. Hołowacz, D. Konopacka-Łyskawa, P. Rybarczyk, and M. Kamiński, "Key issues in modeling and optimization of lignocellulosic biomass fermentative conversion to gaseous biofuels," Renewable Energy, vol. 129, pp. 384-408, 2018.

[5] K. Robak and M. Balcerek, "Review of second generation bioethanol production from residual biomass," Food Technology and Biotechnology, vol. 56, no. 2, pp. 174-187, 2018.

[6] P. Alvira, E. Tomás-Pejó, M. Ballesteros, and M. J. Negro, "Pretreatment technologies for an efficient bioethanol production process based on enzymatic hydrolysis: a review," Bioresource Technology, vol. 101, no. 13, pp. 4851-4861, 2010.

[7] A. Bušić, N. Marđetko, S. Kundas et al., "Bioethanol production from renewable raw materials and its separation and purification: a review," Food Technology and Biotechnology, vol. 56, no. 3, pp. 289-311, 2018.

[8] D. Haldar and M. K. Purkait, "A review on the environmentfriendly emerging techniques for pretreatment of lignocellulosic biomass: mechanistic insight and advancements," Chemosphere, vol. 264, pp. 1-16, 2021.

[9] H. Rodriquez, "Ionic liquids in the pretreatment of lignocellulosic biomass," Acta Innovations, vol. 38, pp. 23-36, 2021.

[10] A. K. Wardani and I. Kusumawardini, "Pretreatment of bagasse (Saccharum oficinarum) for second generation bioethanol production," Jurnal Pangan dan Agroindustri, vol. 3, no. 4, pp. 1430-1437, 2015, in Indonesian.

[11] V. Ferreira, F. Mariana De Oliveira, M. Sabrina Da Silva, and P. Nei Jr., "Simultaneous saccharification and fermentation process of different cellulosic substrate using a recombinan Saccharomyces cerevisiae harbouring the $\beta$-glucosidase gene," Electronic Journal of Biotechnology ISSN, pp. 0717-3458, 2010.

[12] R. Koppram, F. Nielsen, E. Albers et al., "Simultaneous saccharification and co-fermentation for bioethanol production using corncobs at lab, PDU and demo scales," Biotechnology for Biofuels, vol. 6, no. 1, p. 2, 2013. 
[13] Y. You, P. Li, F. Lei, Y. Xing, and J. Jiang, "Enhancement of ethanol production from green liquor-ethanol-pretreated sugarcane bagasse by glucose-xylose cofermentation at high solid loadings with mixed Saccharomyces cerevisiae strains," Biotechnology for Biofuels, vol. 10, no. 1, p. 92, 2017.

[14] N. M. Chauhan, S. T. Hajare, B. Mamo, and A. A. Madebo, "Bioethanol production from stalk residues of chiquere and gebabe varieties of sweet sorghum," International Journal of Microbiology, vol. 2021, Article ID 6696254, 16 pages, 2021.

[15] N. A. Chohan, G. S. Aruwajoye, Y. Sewsynker-Sukai, and E. B. Gueguim Kana, "Valorisation of potato peel wastes for bioethanol production using simultaneous saccharification and fermentation: process optimization and kinetic assessment," Renewable Energy, vol. 146, pp. 1031-1040, 2020.

[16] A. Tesfaw, E. T. Oner, and F. Assefa, "Optimization of ethanol production using newly isolated ethanologenic yeasts," Biochemistry and biophysics reports, vol. 25, Article ID 100886, 2021.

[17] P. J. Van Soest, J. B. Robertson, and B. A. Lewis, "Methods for dietary fiber, neutral detergent fiber, and nonstarch polysaccharides in relation to animal nutrition," Journal of Dairy Science, vol. 74, no. 10, pp. 3583-3597, 1991.

[18] A. Sluiter, B. Hames, R. Ruiz et al., "Determination of structural carbohydrate and lignin in biomass," Technical Report NREL/TP.510-42618, http://www.nrel.gov, 2011.

[19] A. Sluiter and J. Sluiter, "Determination of starch in solid biomass sample by HPLC. laboratory analytical procedure (LAP)," Technical report NREL/TP-510-42624, 2008.

[20] B. Adney and J. Baker, Measurement of Cellulase Activities, Technical Report NREL/TP-510-42628, 2008, https://www. nrel.gov.

[21] M. J. Bailey, P. Biely, and K. Poutanen, "Interlaboratory testing of methods for assay of xylanase activity," Journal of Biotechnology, vol. 23, no. 3, pp. 257-270, 1992.

[22] G. L. Miller, "Use of dinitrosalicylic acid reagent for determination of reducing sugar," Analytical Chemistry, vol. 31, no. 3, pp. 426-428, 1959.

[23] G. E. P. Box and K. B. Wilson, "On the experimental attainment of optimum conditions," Journal of the Royal Statistical Society: Series B (Methodological), vol. 13, no. 1, pp. $1-38,1951$.

[24] A. Darwis, D. R. Nurrochmat, M. Y. Massijaya et al., "Vascular bundle distribution effect on density and mechanical properties of oil palm trunk," Asian Journal of Plant Sciences, vol. 12, no. 5, pp. 208-213, 2013.

[25] M. A. M. Noor and A. M. Dos Mohd, "Physico-chemical properties of oil palm trunk starch," Starch, vol. 51, no. 8-9, pp. 293-301, 1999.

[26] D. M. Mousdale, Biofuels: Biotechnology, Chemistry and Sustainable Development, CRC Press, Boca Raton, FL, USA, 2008.

[27] C. R. Soccol, V. Faraco, S. Karp, L. P. S. Vandenberghe, V. Thomaz-Soccol, and A. Woiciechowski, "Lignocellulosic bioethanol: current status and future perspectives," in Biofuels-Alternative Feedstocks and Conversion Processes, A. Pandey, C. Larroche, S. C. Ricke, C. G. Dussap, and E. Gnansounou, Eds., Academic Press, Oxford, UK, pp. 101-122, 2011.

[28] P. W. Harmsen, W. Hujgen, L. Bermudez, and R. Bakker, Literature Review of Physical and Chemical Pretreatment Processes for Lignocellulosic Biomass, Wageningen UR Food \& Biobased Research, Wageningen, Netherlands, 2010.

[29] R. Singh, A. Shukhla, S. Tiwari, and M. Srivastava, "A review on delignification of lignocellulosic biomass for enhancement of ethanol production potential," Renewable and Sustainable Energy Reviews, vol. 32, pp. 713-728, 2014.

[30] L. Senila, E. Kovacs, D. A. Scurtu et al., "Bioethanol production from vineyard waste by autohydrolysis pretreatment and chlorite delignification via simultaneous saccharification and fermentation," Molecules, vol. 25, no. 11, p. 2606, 2020.

[31] M. J. Gould, "Studies on the mechanism of alkaline peroxide delignification of agricultural residue," Biotechnology and Bioengineering, vol. 27, pp. 225-231, 1985.

[32] A. K. Kumar and S. Sharma, "Recent updates on different methods of pretreatment of lignocellulosic feedstocks: a review," Bioresources and Bioprocessing, vol. 4, no. 1, p. 7, 2017.

[33] K. Urbaniec and R. Grabarczyk, "Raw materials for fermentative hydrogen production," Journal of Cleaner Production, vol. 17, pp. 959-962, 2009.

[34] F. Carvalheiro, C. D. Luís, and F. M. Gíri, "Hemicellulose biorefineries: a review on biomass pretreatments," Journal of Scientific \& Industrial Research, vol. 67, pp. 849-864, 2008.

[35] R. Maryana, D. Ma'rifatun, A. Wheni i, K. W. Satriyo, and W. A. Rizal, "Alkaline pretreatment on sugarcane bagasse for bioethanol production," Energy Procedia, vol. 47, pp. 250-254, 2014.

[36] A. Aguirre-Fierro, H. A. Ruiz, M. A. Cerqueira et al., "Sustainable approach of high-pressure agave bagasse pretreatment foR ethanol production," Renewable Energy, vol. 155, pp. 1347-1354, 2020.

[37] K. Vijayaraghavan and G. M. Akshaya, "Conversion of lignocellulosic sugarcane bagasse waste into bioethanol using indigenous yeast strain," Biosciences Biotechnology Research Asia, vol. 17, no. 3, pp. 559-565, 2020.

[38] P. Prawitwong, A. Kosugi, T. Arai et al., "Efficient ethanol production from separated parenchym and vascular bundle of oil palm trunk," Bioresource Technology, vol. 125, pp. 37-42, 2012.

[39] M. E. Moremi, E. L. Jansen Van Rensburg, and D. C. La Grange, "The improvement of bioethanol production by pentose-fermenting yeasts isolated from herbal preparations, the gut of dung beetles, and marula wine," International Journal of Microbiology, vol. 2020, Article ID 5670936, 13 pages, 2020.

[40] D. C. Montgomery, Response Surface Methods and Designs, John Willy and Sons. Inc, Hoboken, NY, USA, 2005.

[41] V. Gaspersz, Analytical Techniques in Experimental Research, Tarsito, Bandung, Indonesian, in Indonesian, 1992.

[42] Y. Lin, W. Zhang, C. Li, K. Sakakibara, S. Tanaka, and H. Kong, "Factor affecting ethanol fermentation using Saccharomyces cerevisiae BY4742," Biomass and Bioenergy, vol. 47, pp. 395-401, 2012.

[43] H. Zabed, G. Faruq, J. N. Sahu, M. S. Azirun, R. Hashim, and A. N. Boyce, "Bioethanol production from fermentable sugar juice," The Science World Journal, vol. 2014, Article ID 957102, 11 pages, 2014.

[44] S. H. Mohd Azhar, R. Abdulla, S. A. Jambo et al., "Yeasts in sustainable bioethanol production: a review," Biochemistry and biophysics reports, vol. 10, pp. 52-61, 2017.

[45] Y. H. Chang, K. S. Chang, C. Y. Chen, C. L. Hsu, T. C. Chang, and H. D. Jang, "Enhancement of the efficiency of bioethanol production by Saccharomyces cerevisiae via gradually batchwise and fed-batch increasing the glucose concentration," Fermentation, vol. 4, no. 2, p. 45, 2018.

[46] J. Sun, G. Yin, P. Du, and L. Chen, "Optimization of extraction technique of polysaccharides from pumpkin by response surface method," Journal of Medicinal Plants Research, vol. 5, no. 11, pp. 2218-2222, 2011. 